\title{
On the power quality of electrical energy supplied to joint stock company "Aleksandrovsky mine"
}

\author{
Oleg V. Zapanov ${ }^{1}$, Lidiia I. Kovernikova ${ }^{2, *}$ \\ ${ }^{1}$ JSC “Aleksandrovsky Mine”, Trans-Baikal Territory, Mogochinsky district, Davenda village, Russian Federation \\ ${ }^{2}$ Melentiev Energy Systems Institute SB RAS, Irkutsk, Russian Federation
}

\begin{abstract}
Joint Stock Company (JSC) "Mine Aleksandrovsky" is located in the Mogochinsky district of the Trans-Baikal Territory. "Mine Aleksandrovsky" concluded an energy supply agreement with JSC "Chitaenergosbyt" for the purchase of electric energy from it. In accordance with the contract, the electric energy supplier undertakes to supply electric energy that meets the requirements of the current legislation of the Russian Federation. The power quality in the Trans-Baikal Territory in most regions does not meet the requirements of State Standard 32144-2013. Suppliers and the network organization are responsible to consumers for the reliability of its electric energy supply and its quality within the boundaries of their electric networks. Despite the obligations of the contract, the electric energy supplied to "Mine Alexandrovsky" does not meet the requirements. In 2017 the ball mill engine in the shredding department of the gold recovery factory failed as a result of power outages and the supply of low power quality through the $6 \mathrm{kV}$ line. The article provides information on interruptions in power supply over the years of operation of the enterprise, the results of analysis of the power quality, information on damage to electrical equipment caused by low power quality, and economic damage.
\end{abstract}

\section{Introduction}

In Russia, there is a big problem with the power quality [1]. Before the Law "On Electric Power Industry" was enforced in 2003 [2], the country had had an economic mechanism for managing the power quality. It was presented in three documents [3-5] and obliged both the utility and consumers of electrical energy to deal with its quality. According to these documents, in the event of non-compliance with the requirements of the state standard for the power quality, utilities and consumers would have to incur additional financial costs in the amount of discounts/surcharges to the electricity rates [5]. After the adoption of the Law "On Electric Power Industry", these documents [3-5] were canceled. New mandatory regulatory and technical documents governing the relationship between the utility and consumers in the field of power quality have not been developed, although the law states that all entities of the electric power industry are obliged to supply consumers with electrical energy, the quality of which corresponds to "technical regulations and other mandatory requirements". As regards the power quality, the law has not been complied with since it entered into force and is not being implemented at present. After the adoption of the law, market relations began to take root in the power industry. The issues of power quality turned from a technical problem into commercial terms between the consumer of electrical energy and the last resort supplier, which are recorded in the contracts for energy supply and sale/purchase of electrical energy. There are still no regulatory-technical and legal documents that would necessarily regulate the relationship between the consumer and the utility in the field of power quality [1]. The entities of the electric power industry engaged in the power supply to consumers do not want to deal with the power quality themselves, because it is unprofitable, and, as a result, consumers suffer by buying low power quality $[6,7]$.

\section{Description of the Joint Stock Company "Aleksandrovsky Mine"}

One of the consumers, which has suffered many times from the poor power quality, is the JSC "Aleksandrovsky Mine". Its founder is the JSC "Zapadnaya Mining Company" [8]. The JSC "Aleksandrovsky Mine" was founded in 2008 for the development of the Aleksandrovskoye gold-ore deposit in the Mogochinsky district of the Trans-Baikal Territory by open-pit mining. After conducting geological prospecting, a project was developed for the ore extraction and processing, which entailed the construction of the gold recovery plant, hydraulic structures, an ore transportation road, and a rotational camp. In September 2013, the first Aleksandrovsky gold was smelted. It is worth noting that the processing of the mined ore is carried out at the gold recovery plant, where the most efficient beneficiation technologies are adopted

\footnotetext{
* Corresponding author: kovernikova@isem.irk.ru
} 
and modern equipment supplied under the contract is used [9]. The extraction of gold is $92-93 \%$. The gold recovery plant was constructed according to the documentation prepared by the CJSC "TOMS Engineering" [10]. The company has a year-round continuous operation. It has created more than 650 jobs. By investing money in the organization of production, creating jobs, manufacturing products, paying taxes to the state budget, the company contributes to the development of the country's industry and economy. However, from the very beginning of its work, the plant began to experience difficulties due to the low quality of the supplied electrical energy, and, as a result, numerous stoppages in the production process and long downtime of the gold recovery plant.

\section{Power quality problems at the JSC "Aleksandrovsky Mine"}

\subsection{On the power quality in the agreement for energy supply}

The supplier of electricity to the JSC "Aleksandrovsky Mine" is the JSC "Chitaenergosbyt". The JSC "Chitaenergosbyt" in the Trans-Baikal Territory is the last resort supplier, which has to supply (sell) electricity to consumers under the purchase/sale agreements.

A power supply (electricity purchase/sale) contract has been concluded between the JSC "Aleksandrovsky Mine" and JSC "Chitaenergosbyt" [11]. The clause of the contract "Obligations of the Supplier" indicates that the Supplier (the JSC "Chitaenergosbyt") undertakes to "Supply electrical energy (power) under the terms of this contract. The quality and other parameters of the supplied electricity (power) must comply with the requirements of the current legislation of the Russian Federation, including the current technical regulations, and the requirements of State Standard 13109-97 unless the relevant technical regulations come into force. At the time of the contract conclusion, the applicable standard for the power quality was the State Standard 13109-97" [12]. On July 1, 2014, it was replaced by the State Standard 32144-2013 [13], which is the current standard for the power quality. The clause of the contract "Consumer Rights" states that the Consumer (the JSC "Aleksandrovsky Mine") has the right to "receive electrical energy (power) of proper quality under the terms of this contract", and "require maintenance of quality indices of electrical energy at the point of its supply following the requirements of the current legislation of the Russian Federation, including the current technical regulations, and the requirements of the State Standard 13109-97 unless the relevant technical regulations come into force". The contract [11] also indicates that the JSC "Aleksandrovsky Mine" has the third category of power supply reliability.

Consumers in the Mogochinsky District receive electrical energy from the networks of the JSC "Chitaenergo", a branch of the PJSC "IDNC of Siberia". The JSC "Chitaenergosbyt" and the JSC "Chitaenergo" signed an agreement for electricity transmission services
[14]. Under the agreement, the JSC "Chitaenergo" undertakes to supply consumers with electrical energy, the quality of which complies with the technical regulations and other mandatory requirements, including State Standards. The JSC "Chitaenergo" also undertakes "to ensure the transmission of electricity received into its network from points of reception to the points of delivery, the quality and parameters of which must comply with technical regulations, State Standard ...". The JSC "Chitaenergo" also undertakes to transfer electrical energy by the agreed reliability category. Under the agreement, the JSC "Chitaenergo" is responsible for "deviation of power quality indices above the values established by the mandatory requirements adopted under the legislation of the Russian Federation". The obligations on the quality of power supply declared by both the JSC "Chitaenergosbyt" and the JSC "Chitaenergo" have not been fulfilled since the time of the JSC "Aleksandrovsky Mine" connection to the JSC "Chitaenergo" networks.

\subsection{Consequences of the poor power quality for the JSC "Aleksandrovsky Mine"}

Table 1 provides information on the downtime of the gold recovery plant from January 2014 to September 2017 , caused by the poor power quality.

Table 1. Information on the plant downtime.

\begin{tabular}{|l|c|c|}
\hline Year & $\begin{array}{c}\text { Number of } \\
\text { downtimes }\end{array}$ & $\begin{array}{c}\text { Loss of } \\
\text { working time, } \\
\text { hour:min }\end{array}$ \\
\hline 2014 & 130 & $159: 23$ \\
\hline 2015 & 140 & $216: 03$ \\
\hline 2016 & 133 & $141: 43$ \\
\hline $\begin{array}{l}2017 \text { from January } \\
1 \text { to August 13 }\end{array}$ & 691 & $332: 53$ \\
\hline
\end{tabular}

Under the power supply agreement [11], the permissible number of shutdown hours for the third category of power supply reliability is 72 hours per year but no more than 24 hours in a row, including the period of power supply restoration. The analysis of the downtime shown in the Table indicates that the permissible number of hours of the power outage was exceeded each year. In 2017, in 7.5 months, it was exceeded 3.9 times. In August 2017, a $35 \mathrm{kV}$ power transmission tower No. 238 fell. The network company was notified of a possible fall in advance, but the repair team arrived at the scene of the accident one and a half days after the notification. As a result, the plant downtime due to just one power interruption was 43 hours 58 minutes, i.e., from 00:10 h: min on August 11 to 19:08 h: min on August 12.

The plant outages were caused by equipment relay trips due to unacceptable voltage rises and drops, and equipment damage. In 2014, the bearings of the $2.2 \mathrm{MW}$ ball mill electric motor were replaced three times. The front bearing was replaced once and the rear bearing twice. The third replacement of the rear bearing also 
involved welding the shaft. The cause of bearing damage is voltage imbalance, which causes the rotor vibration and, as a result, accelerated wear of the bearings [15, 16]. In 2015, due to short-term voltage rises, the resistance of the discharge circuit of the high-voltage frequency converter of the $2.3 \mathrm{MW}$ mill was damaged three times. In April 2017, during another unexpected power outage, the asynchronous motor of the ball mill failed.

\subsection{Results of the electrical energy tests}

In 2015 and 2017, by the decision of the Administration of the JSC "Aleksandrovsky Mine", the power quality indices [17-23] were measured at the point of its transmission from the JSC "Chitaenergo" to JSC "Aleksandrovsky Mine". The point of transmission is located on the border of the responsibility of electrical networks under the contract for technological connection [24]. The electricity transmission points are cable lugs on outgoing feeders in ten $6 \mathrm{kV}$ indoor switchgear cells at the $35 / 6 \mathrm{kV}$ "Fabrika" substation. In 2017, the power quality indices were measured at cells no. 11 and no. 12 . The measurements were carried out by the electrical laboratory of the JSC "IRMET". The measurement results are shown in Tables 2-6. Indices exceeding the standard values [13] are shown in bold in the Tables. As seen in Tables 2 and 3, at both points of electric power transmission, the limits of the indices $\delta U_{(-)}, \delta U_{(+)}, K_{U}$, $K_{U(\mathrm{n})}, P_{s t}, P_{l t}, K_{2 U}$ are exceeded. The values of the measured indices indicate that the voltage deviations in the phases exceed the established norms, the fluctuations in the voltage values exceed the permissible ones, and that the voltage is significantly unbalanced and nonsinusoidal. The measured values of indices $K_{U}$, $K_{U(n)}, K_{2 U}$ exceed the limits established in [13], both for $95 \%$ of the measurement time and for $100 \%$ of the measurement time.

Table 2. Measured indices of the power quality in cell no. 11 .

\begin{tabular}{|c|c|c|c|c|}
\hline \multirow{2}{*}{ Index } & \multicolumn{3}{|c|}{ Cell no. 11} & \multirow{2}{*}{ Limit } \\
\hline & Phase A & Phase B & Phase C & \\
\hline$\delta U_{(-)}$ & 7.50 & 11.40 & 10.30 & 10.00 \\
\hline$\delta U_{(+)}$ & 10.10 & 5.50 & 9.20 & 10.00 \\
\hline$K_{U 95 \%}$ & 12.03 & 15.02 & 12.88 & 5.00 \\
\hline$K_{U 100 \%}$ & 20.46 & 40.60 & 37.17 & 8.00 \\
\hline$K_{U(3) 100 \%}$ & 14.00 & 24.44 & 16.64 & 4.50 \\
\hline$K_{U(5) 100 \%}$ & 18.97 & 38.50 & 36.55 & 6.00 \\
\hline$K_{U(7) 100 \%}$ & 10.00 & 7.43 & 11.12 & 1.50 \\
\hline$K_{U(9) 95 \%}$ & 1.64 & 1.83 & 1.83 & 1.00 \\
\hline$K_{U(9) 100 \%}$ & 2.88 & 3.19 & 3.67 & 1.50 \\
\hline$K_{U(11) 95 \%}$ & 1.97 & 2.26 & 2.12 & 2.00 \\
\hline$K_{U(11) 100 \%}$ & 3.08 & 3.96 & 2.57 & 3.00 \\
\hline$K_{U(17) 95 \%}$ & 1.26 & 1.56 & 1.21 & 1.50 \\
\hline$K_{U(27) 95 \%}$ & 0.60 & 0.80 & 0.61 & 0.20 \\
\hline$K_{U(27) 100 \%}$ & 1.07 & 1.54 & 0.86 & 0.30 \\
\hline$P_{s t}$ & 2.65 & 1.75 & 1.72 & 1.38 \\
\hline$P_{l t}$ & 1.30 & 0.88 & 0.84 & 1.00 \\
\hline$K_{2 U 95 \%}$ & & 4.87 & & 2.00 \\
\hline$K_{2 U 100 \%}$ & & 10.01 & & 4.00 \\
\hline
\end{tabular}

Table 3. Measured indices of the power quality in cell no. 12.

\begin{tabular}{|c|c|c|c|c|}
\hline \multirow{2}{*}{ Index } & \multicolumn{3}{|c|}{ Cell no. 12} & \multirow{2}{*}{ Limit } \\
\hline & Phase A & Phase B & Phase $\mathrm{C}$ & \\
\hline$\delta U_{(-)}$ & 7.80 & 10.60 & 11.30 & 10.00 \\
\hline$\delta U_{(+)}$ & 9.70 & 6.70 & 9.50 & 10.00 \\
\hline$K_{U 95 \%}$ & 11.71 & 15.16 & 12.40 & 5.00 \\
\hline$K_{U 100 \%}$ & 23.69 & 41.92 & 41.40 & 8.00 \\
\hline$K_{U(3) 100 \%}$ & 15.71 & 25.95 & 18.19 & 4.50 \\
\hline$K_{U(5) 100 \%}$ & 20.18 & 38.62 & 40.88 & 6.00 \\
\hline$K_{U(7) 100 \%}$ & 9.85 & 8.00 & 10.51 & 1.50 \\
\hline$K_{U(9) 95 \%}$ & 1.51 & 1.87 & 1.76 & 1.00 \\
\hline$K_{U(9) 100 \%}$ & 2.63 & 3.38 & 3.51 & 1.50 \\
\hline$K_{U(11) 95 \%}$ & 1.84 & 2.27 & 2.27 & 2.00 \\
\hline$K_{U(11) 100 \%}$ & 2.82 & 3.72 & 2.94 & 3.00 \\
\hline$K_{U(17) 95 \%}$ & 1.13 & 1.59 & 1.30 & 1.50 \\
\hline$K_{U(27) 95 \%}$ & 0.51 & 0.85 & 0.62 & 0.20 \\
\hline$K_{U(27) 100 \%}$ & 0.90 & 1.77 & 0.86 & 0.30 \\
\hline$P_{s t}$ & 3.18 & 2.08 & 1.50 & 1.38 \\
\hline$P_{l t}$ & 1.30 & 0.87 & 0.72 & 1.00 \\
\hline$K_{2 U 95 \%}$ & & 4.96 & & 2.00 \\
\hline$K_{2 U 100 \%}$ & & 8.34 & & 4.00 \\
\hline
\end{tabular}

The data in Tables 4-6 indicate that at both points of the electrical energy transmission there were a large number of overvoltages and voltage dips.

Table 4. Number of overvoltages

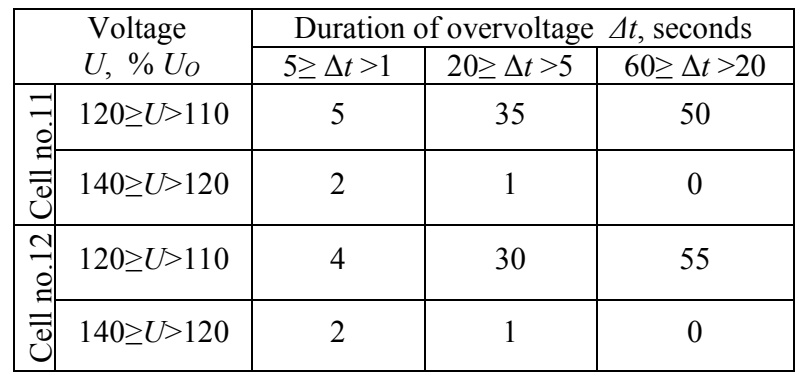

Table 5. Number of voltage dips

\begin{tabular}{|c|c|c|c|c|}
\hline \multirow{2}{*}{\multicolumn{2}{|c|}{$\begin{array}{l}\text { Voltage } \\
U, \% U_{O}\end{array}$}} & \multicolumn{3}{|c|}{ Duration of voltage dip $\Delta t$, seconds } \\
\hline & & $0.2 \geq \Delta t>0.01$ & $0.5 \geq \Delta t>0.2$ & $1 \geq \Delta t>0.05$ \\
\hline$=$ & $90>U \geq 85$ & 27 & 19 & 17 \\
\hline き & $85>U \geq 70$ & 2 & 5 & 7 \\
\hline$\overline{0}$ & $70>U \geq 40$ & 6 & 0 & 0 \\
\hline & $90>U \geq 85$ & 22 & 33 & 6 \\
\hline 7 & $85>U \geq 70$ & 2 & 2 & 4 \\
\hline$\overline{0}$ & $70>U \geq 40$ & 6 & 0 & 0 \\
\hline U & $40>U \geq 10$ & 5 & 0 & 0 \\
\hline
\end{tabular}

Table 6. Number of voltage dips

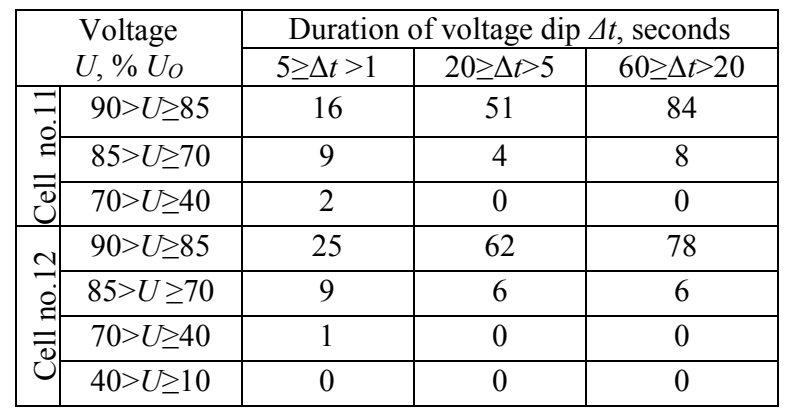


In addition to the listed violations, the devices measuring the power quality indices recorded a power supply failure at both cells. The graphs of active and reactive powers in Figs. 1 and 2 show that at about 10 minutes past $9 \mathrm{pm}$, the values of active and reactive power are zero, which means that on April 12, 2017, there was a power outage at the gold recovery plant.

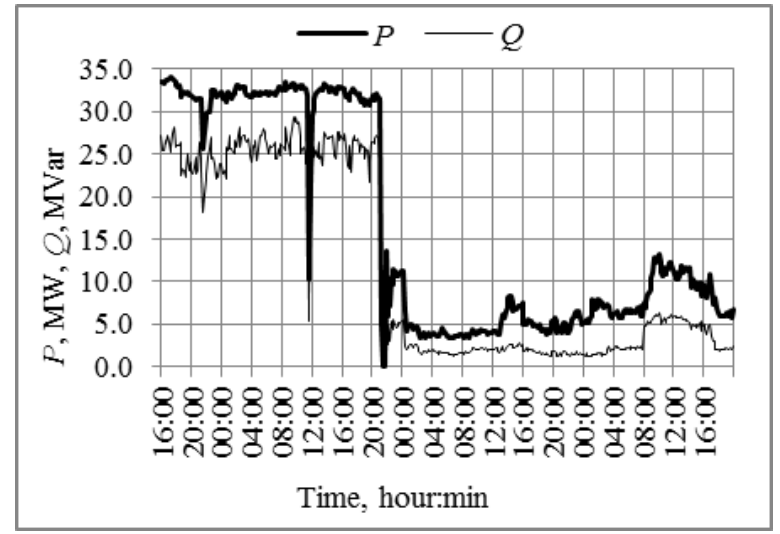

Fig. 1. Graphs of active and reactive powers at cell no.11.

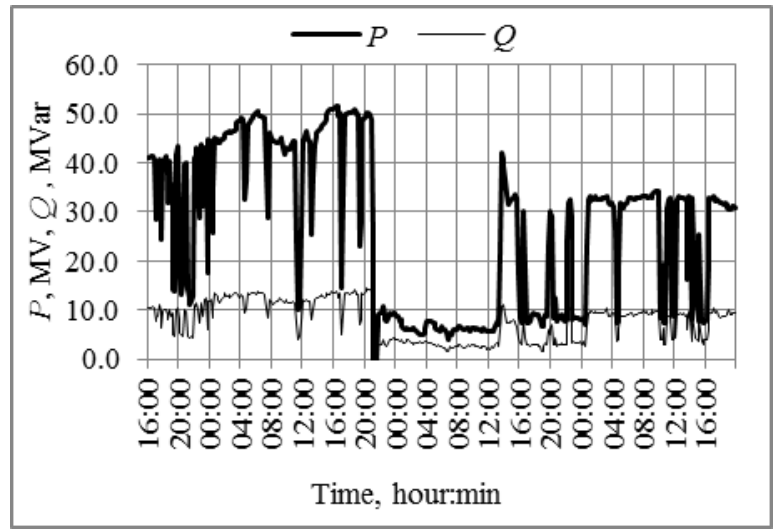

Fig. 1. Graphs of active and reactive powers at cell no.12.

\subsection{Economic damage caused by poor power quality}

The company calculated the economic damage for the time of lost working hours, shown in Table 1, in the form of lost revenue. The damage assessment results are shown in Table 7.

Table 7. Economic damage.

\begin{tabular}{|l|c|c|c|}
\hline Year & $\begin{array}{c}\text { The average } \\
\text { productivity } \\
\text { of metal, } \\
\text { g/hour }\end{array}$ & $\begin{array}{c}\text { The amount of } \\
\text { underproduced } \\
\text { metal, } \\
\mathrm{g}\end{array}$ & $\begin{array}{c}\text { Lost } \\
\text { revenue, } \\
\text { thousand } \\
\text { roubles }\end{array}$ \\
\hline 2014 & 40 & 6360 & 9406 \\
\hline 2015 & 112 & 24192 & 50924 \\
\hline 2016 & 157 & 22137 & 59416 \\
\hline $\begin{array}{l}\text { January 1 to } \\
\text { August 13 }\end{array}$ & 157 & 52124 & 119885 \\
\hline Total & & 68703 & 239631 \\
\hline
\end{tabular}

In addition to the losses due to lost revenues, the JSC "Aleksandrovsky Mine" had financial losses in the form of the cost of equipment that was installed instead of the damaged one. The company also incurred the costs to cover the repair of the $35 \mathrm{kV}$ power transmission tower after the fall. The JSC "Chitaenergo" repair team that arrived at the scene of the accident did not have the technical tools to eliminate the accident. The JSC "Aleksandrovsky Mine" was forced to provide them with its equipment, including a bulldozer, an excavator, and two mining dump trucks. The costs of the company amounted to 233435 rubles.

\subsection{Complaints of the JSC “Aleksandrovsky Mine" about the poor power quality}

Due to the grave consequences caused by the low power quality supplied to the JSC "Aleksandrovsky Mine", the administration of the company has repeatedly addressed complaints and requests for assistance in improving the power quality to various authorities of the Trans-Baikal Territory since the JSC "Aleksandrovsky Mine" was connected to the JSC "Chitaenergo" electrical networks, i.e., since 2013. Letters about the low power quality have been repeatedly sent to the governor of the TransBaikal Territory, the chairman of the government, the first deputy chairman of the government, the minister of natural resources and industry, the director of the JSC "Chitaenergo", the director of the JSC "Chitaenergosbyt". The issues of the power quality supplied to the JSC "Aleksandrovsky Mine" have been repeatedly discussed at the meetings of the Center for Ensuring the Safety of Power Supply in the Trans-Baikal Territory. As a result of the appeals, all the governing bodies of the Trans-Baikal Territory acknowledge the existence of the problem of poor quality, and the fact that that its source is the electrified railway. Railway traction consumers cause voltage imbalance, nonsinusoidality and fluctuations. As a result, the power quality at the consumers receiving electrical energy from a network shared with traction load does not meet the established requirements [13].

The JSC "Aleksandrovsky Mine" is not the only consumer that suffers from the poor quality. The meetings of the Center for Ensuring the Safety of Power Supply on the Territory of the Trans-Baikal Territory have repeatedly considered the issue of the negative impact of voltage imbalance spreading throughout the entire electrical network from the network supplying the railway on the reliability of generating equipment, primarily the Kharanorskaya condensing power plant. The voltage imbalance in the electrical network, to which the plant is connected, leads to the disconnection of power units of the plant by relay protection devices against negative sequence currents, and to the consumer load disconnection by the emergency control devices.

The letter from the director of the JSC "Chitaenergosbyt" to the Federal Antimonopoly Service for the Trans-Baikal Territory dated 11.23.2015 [25] contains the complaints about the poor power quality received by the JSC 'Chitaenergosbyt' in 2014 and 
2015, from residents of the town of Mogocha, the village of Ust-Karsk, OJSC "Priisk Ust-Kara", LLC RSO "Teplovodokanal", and others. In December 2017, the website of the newspaper "Zabaikalsky Rabochy" reported that "At night from December 9 to December 10, 17 motors and 1 pump at boiler houses and water supply facilities failed in several populated areas of the Mogochinsky District due to power variation. An emergency state was declared in the district" [7].

In August 2017, the JSC "Aleksandrovsky Mine" appealed to the Arbitration Court of the Trans-Baikal Territory with a statement of claim against the JSC "Chitaenergosbyt" to recover the cost of low power quality supplied in April 2017 under the power supply agreement and to compensate for the amount of damage associated with the need to restore the damaged ball mill motor. The statement also contained a claim against the PJSC "IDNC of Siberia" on the company's obligation, within three calendar months from the date of entry into force of the decision of the Arbitration Court, to install a STATCOM (a device for regulating reactive power) on the buses of the $110 / 35 / 6 \mathrm{kV}$ "Verkhnyaya Davenda" substation or the $35 / 6 \mathrm{kV}$ "Fabrika" substation to improve the power quality. In August 2020, three years have passed since the consideration of the case by the Arbitration Court.

\section{Conclusions}

1. The JSC “Aleksandrovsky Mine" has been facing the problem of the electrical energy quality since its connection to the electrical networks of the JSC "Chitaenergo", i.e., since 2013. The company incurs financial losses due to the poor power quality. Yearslong numerous appeals of the Administration of the JSC "Aleksandrovsky Mine" to higher authorities turned into long-term correspondence and rarely found efficient support and assistance.

2. In Russia, there is no legal mechanism regulating the relationship between the consumers and suppliers of electrical energy in terms of its quality. Last resort suppliers are monopolists in the areas to which they sell electricity. They dictate their terms to consumers but do not fulfill their obligations stipulated in the energy supply agreement.

3. There is no governmental control over such monopolists. The state does not protect the interests of the consumers. In this regard, it is necessary to create an organization of specialists, provided with the required technical tools, which would have the right to conduct expert assessments. Moreover, this organization should be capable of providing legal support to the consumers and deal with the problems of electrical energy quality.

The research is conducted in the framework of the research projects №AAAA-A17-117030310432-9 and №AAAA-A17117030310438-1 of the program of fundamental research of Siberia Branch of the Russian Academy of Sciences III.17.4.

\section{References}

1. L.I. Kovernikova, V.V. Sudnova, R.G. Shamonov, et al., Power quality: present-day state, problems and proposals to their solutions (Nauka, 2017)

2. Federal Law of the Russian Federation No. 35-RF "On the Electric Power Industry" of March 26, 2003

3. Rules for connecting consumers to a generalpurpose network on the terms of influence on the power quality, Industrial Power Engineering, No. 8, 45-48 (1991)

4. Rules for applying discounts and surcharges to tariffs for the power quality, Industrial Power Engineering, No. 8, 49-51 (1991)

5. Price list No. 09-01. Electricity and heat rates (M .: Preiskurantizdat, 1990)

6. L.I. Kovernikova, A.V. Serkov A.V., R.G. Shamonov, Electricity quality control in Russia, Operational Control in the Electric Power Industry. Personnel Training and Maintenance of their Qualifications, No. 1, 48-61 (2019)

7. Zabaikalsky Rabochy newpaper "Emergency state was introduced in the Mogochinsky district due to failure of 17 engines and a pump in boiler rooms", http: //zabrabochy.rf/news/189133/

8. JSC "Mining and ore company "Zapadnaya"", http://www.zapadnaya.ru

9. Contract No. 110418 dated April 26, 2011, between Outotec (Finland) Oy (Espoo, Finland) and Closed Joint Stock Company "Aleksandrovsky Mine".

10. TOMS Group of Companies, http://www.tomsgroup.ru/

11. Power supply agreement No. 050641 dated January 15, 2013, Chita.

12. State Standard 13109-97. Electrical Energy. Electromagnetic compatibility of technical equipment. Power quality limits in public electrical systems. (IPK. Publishing House of Standards. M.: 2005)

13. State Standard 32144-2013. Electric Energy. Electromagnetic compatibility of technical equipment. Power quality limits in public power supply systems (M.: Standartinform, 2014)

14. Agreement No. 18.7500.2896.13 for electricity transmission services, of July 22, 2013, Chita

15. A.L. Tserazov, N.I. Yakimenko, Information materials No. 70. Research on the influence of voltage imbalance and non-sinusoidality on the operation of asynchronous motors (State Energy Publishing House. Moscow. Leningrad. 1963)

16. M.A. Silaev, V.N. Tulskiy, R.G. Shamonov, Influence of system operation on voltage nonsinusoidality and imbalance in the main electrical networks, Energy of Russia in the 21 st century. Innovative development and control: Collected 
papers of the All-Russian Conference "Energy of Russia in the 21 st century. Innovative Development and Control" (Irkutsk, Russia, September 1-3, 2015). Irkutsk, 189-194 (2015)

17. Protocol No. $2347 / 128$ of electrical energy tests for compliance with the requirements of State Standard $32144-2013$ at the 220/110/35/10/6 kV Mogocha substation (110 kV outdoor switchgear, 110-73 Verkhnyaya Davenda-Mogocha overhead line) (2015)

18. Protocol No. $2479 / 114$ of tests of electrical energy for compliance with the requirements of State Standard 32144-2013 at the 110/35/6 kV "Verkhnyaya Davenda" substation (outdoor switchgear-35 kV, 35-238 "Verkhnyaya DavendaKudecha" overhead line) (2015)

19. Protocol No. 2349/97 of tests of electrical energy for compliance with the requirements of State Standard $32144-2013$ at the $110 / 35 / 6 \mathrm{kV}$ "Verkhnyaya Davenda" substation (indoor switchgear- $6 \mathrm{kV}$, cell no. 12, feeder no. 4 "Aleksandrovsky Mine" (2015)

20. Protocol No. 2347-170411 of electrical energy tests for compliance with the requirements of State Standard 32144-2013 at the 35/6 kV Fabrika substation (indoor switchgear-6 kV, cell no. 11) (2017)

21. Protocol No. 2349-170411 of electrical energy tests for compliance with the requirements of State Standard 32144-2013 at the 35/6 kV Fabrika substation (indoor switchgear-6 kV, cell no. 12) (2017)

22. Protocol No. 2337-170411 electrical energy tests for compliance with the requirements of State Standard $32144-2013$ at the $110 / 35 / 6 \mathrm{kV}$ "Verkhnyaya Davenda" substation (Outdoor switchgear-110 kV, 110-73-"Davenda-Mogocha" overhead line) (2017)

23. Protocol No. 2484-170411 of electrical energy tests for compliance with the requirements of State Standard 32144-2013 at the 110/35/6 kV "Verkhnyaya Davenda" substation (outdoor switchgear-110 kV, 110-72 "KsenyevskayaDavenda" overhead line) (2017)

24. Contract No. 20.7500.763.12 for the technological connection of July 10, 2012, Chita

25. Letter of the General Director of the JSC "Chitaenergosbyt" to the Office of the Federal Antimonopoly Service for the Trans-Baikal Territory dated 23.11.2015. Chita 